\title{
TEKNIK TOTAL PHYSICAL RESPONS UNTUK MENINGKATKAN KEMAMPUAN BERBICARA ANAK TUNARUNGU
}

\author{
(TOTAL PHYSICAL RESPONSE TECHNIQUES TO IMPROVING THE ABILITY OF \\ SPEAKING DEAF CHILDREN)
}

\author{
Ayinun Mardhiati ${ }^{1)}$, Umar Mansyur ${ }^{2)}$ \\ ${ }^{1)}$ Fakultas Ilmu Budaya, Universitas Hasanuddin \\ ${ }^{2)}$ Fakultas Sastra, Universitas Muslim Indonesia \\ Email: 1)ainun_mynely@yahoo.com, ${ }^{2)}$ umar.mansyur@umi.ac.id
}

\begin{abstract}
Abstrak
Tulisan ini bertujuan mengkaji teknik Total Physical Respons sebagai upaya untuk meningkatkan kemampuan berbicara anak tunarungu. Pada dasarnya, tunarungu memiliki keterbatasan dalam berbicara karena terkendala dalam proses imitasi bahasa. Pendengaran anak tunarungu kurang berfungsi, sehingga aktivitas kebahasaannya dialihkan pada visualisasi dan kegiatan motorik. Adanya hambatan akibat gangguan pendengaran turut membuat kemampuan berbicara dan membacanya menjadi terganggu. Bentuk keterbatasan ujaran anak tunarungu terdapat pada ritme dan pemenggalan frasa. Suaranya agak monoton dan tidak ekspresif, serta tidak dapat menghasilkan warna suara yang alami. Selain itu, terdapat kesalahan artikulasi pada bunyi-bunyi ujaran tertentu, sehingga dapat dikatakan bahwa kurang dapat dipahaminya ujaran individu anak tunarungu lebih banyak diakibatkan oleh tidak normalnya ritme dan pemenggalan frasa daripada karena kesalahan artikulasi. Untuk meningkatkan kemampuan berbicara anak tunarungu dapat dilakukan dengan menggunakan teknik Total Physical Response (TPR). TPR merupakan sebuah teknik pengajaran bahasa yang lebih menekankan pada proses visualisasi dan perintah langsung. Teknik TPR menjadi upaya pembinaan intensif alternatif yang dapat menstimulasi perkembangan bahasa produktif serta pemahaman anak tunarungu.
\end{abstract}

Kata Kunci: Berbicara, Anak Tunarungu, Total Physical Respons

\begin{abstract}
This paper aims to explain the technique of Total Physical Response to improve the ability of speaking deaf children. Basically, the deaf has limitations in speaking because it is constrained in the process of imitation of language. Hearing of deaf children is less functional, so the activity their language diverted on visualization and motor activities. The existence of obstacles due to hearing loss also makes the ability to speak and read it becomes disrupted. The forms of hearing impaired deaf limitations are found in rhythm and beheading of phrases. His voice is rather monotonous and not expressive, and can not produce a natural sound color. In addition, there is an articulation error in certain speech sounds, so it can be said that the lack of comprehension of the individual speech of a deaf child is more due to the non-normal rhythm and phrase-break rather than by articulation error. To improve speech ability of children with hearing impairment can be done by using technique of Total Physical Response (TPR). TPR is a language teaching technique that emphasizes the visualization process and direct command. The TPR technique becomes an alternative intensive coaching effort that can stimulate the development of productive language as well as the understanding of deaf children.
\end{abstract}

Keywords: Speaking, Deaf Children, Total Physical Response

\section{PENDAHULUAN}

Kesadaran pentingnya interaksi dan komunikasi (tidak hanya bahasa) sebagai dasar bagi semua pembelajaran dan penggunaan pendekatan yang komprehensif menjadi orientasi pendidikan Anak 
Berkebutuhan Khusus (ABK), yang dalam tulisan ini secara khusus merujuk pada anak tunarungu. Hal ini tentu berhubungan langsung dengan bentuk-bentuk pragmatik saat anak berkomunikasi, pun kemampuannya berinteraksi dalam membentuk kehidupan sosialnya.

Hingga saat ini telah banyak perubahan dalam pendidikan bagi ABK. Perubahan tersebut termasuk perubahan dalam kesadaran dan sikap, keadaan, metodologi, penggunaan konsep-konsep terkait dan sebagainya. Perubahan tidak hanya relevan bagi kepentingan dan pengayaan anak berkebutuahn khusus, tetapi juga bagi pengayaan semua yang terlibat; anak-anak (dengan atau tanpa kebutuhan khusus), keluarganya, guruguruya, komunitas sekolahnya, dan masyarakat secara keseluruhan.

Konsekuensi yang paling penting dari perubahan tersebut adalah pengakuan dan penghargaan akan adanya keragaman. Hal ini juga menghasilkan upaya-upaya untuk "membawa kembali" ke dalam masyarakat mereka yang sebelumnya telah dipisahkan oleh sebagian besar masyarakat karena mereka dianggap berbeda. Di antara yang telah dipisahkan tersebut, ditemukan fakta bahwa anak-anak yang mempunyai hambatan belajar dan perkembangannya. Hambatan-hambatan tersebut disebabkan di antaranya oleh kecacatan.

Setiap anak tunarungu membutuhkan aktualisasi diri. Aktualisasi diperlukan untuk menumbuhkan keper-cayaan diri, memperluas wawasan, juga membentuk kreativitas. Salah satu bentuk aktualisasi diri yang memungkinkan berinteraksi dalam komunitas seragam maupun plural dilakukan melalui perilaku verbal, yakni berkomunikasi.

Tujuan berkomunikasi berkaitan erat dengan pilihan ragam bahasa yang digunakan. Tujuan tutur untuk mendidik, merayu, memarahi, meminta tolong, menyanjung, dan sebagainya, mengandung pilihan kata yang berbedabeda (Mansyur, 2017).

\section{PEMBAHASAN}

\section{Kemampuan Berbicara Anak Tunarungu}

Kemampuan berkomunikasi atau berbicara memiliki peran sentral. Perkembangan intelektual, sosial, dan emosional seseorang sangat dipengaruhi oleh kemampuan berbahasanya. Bahasa diharapkan bisa membantu seseorang untuk mengenal dirinya, budaya, mengemukakan gagasan dan perasaan, berpartisipasi dalam masyarakat. Pengguna bahasa juga diupayakan mampu mengeksplorasi dan menggunakan kemampuan-kemampuan analitis dan imaginatifnya. Demikian halnya dalam proses belajar mengajar di sekolah, diperlukan satu bentuk komunikasi lisan yang akan mengefektifkan pencapaian tujuan pembelajaran.

Dalam konteks pembelajaran berbicara di sekolah, terkadang siswa tidak dilatih dan diarahkan untuk mampu berbicara dengan memperhatikan ketepatan dan kelancaran berbicara. Terkadang aspek yang dipentingkan hanyalah ketuntasan materi pelajaran tanpa memperhitungkan peningkatan kompetensi siswa dalam berbicara, sehingga kemampuan dan pengalaman siswa terhadap keterampilan berbicara hanya sebatas mampu menyampaikan meteri yang diberikan (Umiaty \& Mansyur, 2017:14).

Dalam hal berbicara, anak tunarungu memiliki hambatan akibat gangguan pendengarannya. Berdasarkan lingkungan, menurut Delphie (2006:112) bahwa anak tunarungu tumbuh dan hidup dalam lingkungan terisolir, sehingga mereka 
membutuhkan interaksi sosial dan perasaan diterima oleh orang-orang di sekelilingnya.

Anak tunarungu mempunyai tingkat gangguan pendengarannya yang berbedabeda. Ciri-ciri umum yang biasa tampak dari anak tunarungu, antara lain: artikulasi bicaranya jelek, mendengar lebih jelas bila berhadapan muka dengan yang diajak bicara, tampak sering bingung atau melamun, bersikap acuh tak acuh, kadang bersikap agresif, perkembangan sosialnya terbelakang, sering meminta agar orang mengulang kalimatnya, jika bicara sering membuat suara-suara tertentu, bicara sering menggunakan tangan (Hermin, 2006:17).

Menurut Soemantri (2006), tidak seperti jenis kecacatan lainnya, gangguan fisiologis anak tunarungu menyebabkan kendala dalam berbicara. Hal ini menyebabkan mereka tidak dapat melakukan proses peniruan bunyi bahasa yang merupakan syarat mutlak dalam pengajaran berbahasa. Meskipun demikian, proses berbahasa tetap berlangsung pada anak tunarungu. Pengajaran berbahasanya dialihkan pada peniruan visual terhadap apapun disekitarnya.

Tunarungu memiliki keterbatasan berbicara, karena terkendala dalam proses imitasi bahasa. Pendengarannya kurang berfungsi, sehingga aktivitas kebahasaannya dialihkan pada visualisasi dan kegiatan motorik. Sepintas fisik mereka tidak mengalami kelainan tetapi sebagai dampak dari ketunarunguannya, anak tunarungu memiliki karakteristik yang khas.

Akibat terbatasnya ketajaman pendengaran, anak tunarungu tidak mampu mendengar dengan baik. Dengan demikian pada anak tunarungu tidak terjadi proses peniruan suara setelah masa meraban, proses peniruannya hanya terbatas pada peniruan visual. Selanjutnya, dalam perkembangan bicara dan bahasa, anak tunarungu memerlukan pembinaan secara khusus dan intensif sesuai dengan kemampuan dan taraf ketunarunguannya.

Perkembangan kemampuan bahasa dan komunikasi anak tunarungu terutama yang tergolong tunarungu total tidak mungkin untuk sampai pada penguasaan bahasa melalui pendengarannya, melainkan harus melalui penglihatannya dan memanfaatkan sisa pendengarannya.

Selain itu, anak tunarungu terhambat memahami struktur kalimat yang kompleks. Di sekolah, penerapan latihan-latihan berbahasa dengan menggunakan keterampilan metalinguistik sangat penting. Metalinguistik diartikan sebagai penggunaan bahasa untuk mengomentari ucapanucapan dalam komunikasi yang salah ucap. Misalnya "kapang dara bang ri" dikomentari secara langsung saat kejadian dengan "kapal udara terbang sendiri" (Ashman dalam Delphie, 2006).

Dilihat dari segi intelegensi, pada dasarnya intelegensi anak tunarungu sama seperti anak yang normal, ada yang mempunyai intelegensi tinggi, rata-rata, dan rendah. Sebagaimana dijelaskan oleh Somad \& Hernawati (1996:35) bahwa pada umumnya anak tunarungu memiliki intelegensi normal atau rata-rata, akan tetapi karena perkembangan intelegensi sangat dipengaruhi oleh perkembangan bahasa maka anak tunarungu akan menampakkan intelegensi yang rendah disebabkan kesulitan memahami bahasa.

Berdasarkan pendapat tersebut, maka tidak mengherankan kalau anak tunarungu pada akhirnya memperlihatkan prestasi belajar yang rendah jika dibanding dengan anak normal lainnya.

Perkembangan kognitif anak tunarungu menurut Delphie (2006:106) secara umum cukup baik, khususnya dalam segi berpikir dan pemahaman. Mereka 
memiliki perkembangan kognisi dikarenakan ada hubungan erat antara perkembangan berbahasa dengan berpikir. Keterampilan kognitif berkaitan dengan kemampuan akademik. Umumnya kemampuan mengingat anak tunarungu sangat singkat. Hanya hitungan beberapa detik tidak sampai menit (Delphie, 2006:111).

Dilihat dari segi bahasa anak tunarungu, Somad \& Hernawati (1996:35) menjelaskan bahwa perkembangan bahasa dan bicara anak tunarungu sampai masa meraban tidak mengalami hambatan, karena meraban merupakan kegiatan alami pernafasan dan pita suara. Setelah masa meraban perkembangan bahasa dan bicara anak tunarungu berhenti.

Anak tunarungu memiliki kecenderungan gangguan psikologis. Hal ini dinyatakan Gregory (dalam Dhelpie, 2006:111) bahwa satu dari tujuh anak yang memiliki gangguan pendengaran mempunyai permasalahan berkaitan dengan kesehatan mental. Kesehatan mental ini mengarah pada kelainan psikis (schizophrenia), paranoid, kelainan emosi secara psikis (affective psychosis), dan kemuraman (depression).

Anak tunarungu mempunyai kesulitan psikologis yang diperoleh dari sejumlah faktor eksternal, seperti kurangnya bimbingan orang tua dan keluarga, kesadaran orang-orang disekitarnya terhadap permasalahan anak tunarungu, lingkungan hidup, budaya, dan model peran dari anak tunarungu.

Banyak penelitian yang telah dilakukan tentang pemahaman ujaran anak tunarungu pada berbagai tingkatan ketunarunguannya. Pemahaman ujaran individu tunarungu bervariasi dari hampir normal hingga tak dapat dipahami sama sekali, kecuali oleh mereka yang mengenalnya dengan baik.
Hasil penelitian terkenal mengenai aspek bahasa anak tunarungu dilakukan oleh Hudgins \& Numbers pada tahun 1942. Mereka menganalisis ujaran 192 anak tunarungu berat dan berat sekali. Mereka menemukan bahwa kekurangan dalam ujaran anak-anak ini adalah dalam hal ritme dan pemenggalan frasa. Suaranya agak monoton dan tidak ekspresif, serta tidak dapat menghasilkan warna suara yang alami. Mereka juga menemukan bermacammacam kesalahan artikulasi pada bunyibunyi ujaran tertentu (kesalahan artikulasi vokal biasanya lebih sering daripada konsonan). Mereka menyimpulkan bahwa kurang dapat dipahaminya ujaran individu tunarungu itu lebih banyak diakibatkan oleh tidak normalnya ritme dan pemenggalan frasa daripada karena kesalahan artikulasi.

Berdasarkan penelitian yang telah dilakukan Furth (dalam Somad \& Hernawati, 1996) yang menyimpulkan bahwa defisit bahasa tidak merintangi seorang tunarungu untuk berpikir secara normal. Bila ia mengontrol pengaruh bahasa terhadap sejumlah besar tugas kognitif, ditemukannya bahwa kinerja subyek tunarungu sedikit sekali perbedaannya dengan sebayanya yang nontunarungu. Jika perbedaan itu muncul, hanya diakibatkan oleh kurangnya pengalaman atau tidak dikenalnya tugastugas atau konsep-konsep yang diujikan, bukan karena defisit kognitif secara umum akibat ketunarunguan dan/atau akibat defisit bahasa.

Tidak semua anak tunarungu kehilangan seluruh pendengarannya (tunarungu total). Di antara mereka masih mempunyai sisa pendengaran yang dapat digunakan. Dalam hal ini, menurut Hallahan (dalam Delphie, 2006:34) diperlukan pendekatan khusus dalam kegiatan belajar-mengajar yang berkaitan 
dengan aspek komunikasi, seperti pemberian latihan auditori; dikondisikan pada berbicara bibir (lips reading); penggunaan bahasa isyarat dan ejaan huruf dengan jari-jari (sign language and finger spelling).

\section{Teknik Total Physical Respons}

Pelaksanaan pembelajaran berbahasa dikemas ke dalam empat aspek keterampilan berbahasa, yakni keterampilan menyimak, membaca, berbicara, dan menulis. Keempat aspek keterampilan berbahasa tersebut telah menjadi landasan pembelajaran mulai tingkat sekolah dasar hingga perguruan tinggi (Mansyur, 2016:158).

Untuk meningkatkan kemampuan berbicara anak tunarungu yang memiliki gangguan pendengaran, dapat dilakukan dengan menggunakan teknik Total Physical Response (TPR). TPR merupakan sebuah metode pengajaran bahasa yang lebih menekankan pada proses visualisasi dan perintah langsung. Pengajaran ini lebih mengutamakan kegiatan langsung berhubungan dengan kegiatan fisik (physical) dan gerakan (movement). TPR merupakan metode pembelajaran bahasa yang disusun pada koordinasi perintah (command), ucapan (speech) dan gerak (action); dan berusaha mengajarkan bahasa melalui aktivitas fisik (www.tpr.com).

TPR pada dasarnya digunakan untuk pengajaran bahasa kedua (bahasa Inggris), khususnya anak usia dini. Total Physical Response lebih memusatkan pengajaran pada efektivitas visualisasi dan motorik untuk mempermudah pemahaman dan berbicara siswa. Hal ini mempunyai kesamaan dengan pengajaran bahasa anak tunarungu.

Efektivitas pengajaran TPR telah ada pada penelitian-penelitian terdahulu.
Fransisco J. Cobello tahun 2003 berhasil menerapkan TPR bagi anak-anak di Amerika dalam pengajaran bahasa Jepang. Hal ini juga dipertegas oleh Eli Tohonan tahun 2007 yang telah mendapatkan hasil perkembangan bahasa Inggris anak usia dini dalam penerapan Total Physical Response.

Pengajaran bahasa anak tunarungu dan pengajaran bahasa kedua memiliki persamaan orientasi dalam hal peningkatan produktivitas berbahasa (berbicara). Pengajaran bahasa kedua dilakukan karena keterbatasan pemakaiannya, sedangkan pengajaran bahasa pada anak tunarungu harus dilakukan untuk mempermudah interaksi sosialnya.

\section{Teori Pembelajaran Bahasa TPR}

Dalam pembelajaran bahasa diperlukan sebuah teknik pembelajaran yang inovatif. Menurut Mansyur, (2016:159), penggunaan berbagai teknik dan metode yang inovatif tentu dapat menciptakan situasi pembelajaran yang kondusif. Peserta didik akan ikut terlibat secara langsung dalam menyerap informasi dan menyatakan kembali hasil rekaman informasi yang diperolehnya sesuai dengan kemampuan individu peserta didik.

Teori pembelajaran bahasa TPR (Mukti Penny) yang diterapkan pertama kali oleh Asher ini mendeskripsikan perkembangan pembelajaran verbal anak. Asher menyajikan 3 hipotesis pembelajaran yang berpengaruh, antara lain:

1) Bio-Program

Sejak lahir, anak memiliki bioprogram untuk mempelajari dan mengembangkan bahasa pertama dan kedua. Bio-program bawaan yang spesifik untuk pembelajaran bahasa menggambarkan sebuah alur yang optimal untuk pengembangan bahasa pertama dan kedua. 
Dalam bio-program ini ada 3 proses, yaitu (i) anak mengembangkan kemampuan mendengarkan sebelum mereka mengembangkan kemampuan berbicara, (ii) kemampuan anak dalam mendengarkan tercapai ketika anak diminta untuk merespon bahasa lisan dengan tindakan (fisik) dalam bentuk perintah, dan (iii) ketika dasar mendengarkan telah dicapai, maka kemampuan berbicara akan diproduksi secara alamiah.

\section{2) Lateralisasi Otak}

Lateralisasi otak menggambarkan fungsi pembelajaran yang berbeda pada otak kiri dan kanan. Menurut pengamatan Asher, TPR cenderung diarahkan pada pengajaran otak kanan, sedangkan sebagaian besar metode pengajaran bahasa diarahkan pada pengajaran otak kiri.

\section{3) Pengurangan Tekanan}

Stress mempengaruhi aktivitas belajar dan apa yang akan dipelajari oleh peserta didik. Stress yang lebih rendah kapasitasnya membuat pembelajaran menjadi lebih baik.

Total Physical Response (TPR) dapat diadaptasikan dalam pengajaran bahasa anak tunarungu. Hal ini sesuai dengan pernyataan bahwa TPR didasarkan pada hipotesis bahwa otak manusia mempunyai program biologis yang secara alami dapat mengetahui setiap bahasa di dunia termasuk bahasa isyarat dari orang-orang yang tuli. Anak tunarungu yang dimaksud bukanlah tunarungu total (deaf), melainkan anak yang memiliki kesulitan mendengar (hard of hearing/ hearing impairment).

Teknik Total Physical Response menjadi upaya pembinaan intensif alternatif yang dapat menstimulasi perkembangan bahasa produktif serta pemahaman siswa tunarungu. Hal ini dipertegas oleh Lewis (dalam Delphie, 2006:112) bahwa anak tunarungu memiliki kesulitan membaca, mereka juga perlu dibekali suatu metode pelajaran yang lebih menekankan pada pengucapan bahasa.

Menurut Mardhiati (2010), anak tunarungu mampu mengerti bahasa seseorang dengan memperhatikan gerakan bibir (membaca ujaran). Sebagai bentuk pengajaran, pengucapan kata dilakukan secara perlahan-lahan agar mereka memperhatikan secara seksama hingga mampu mengikuti dan mulai mencontoh bahasa tersebut.

Selain itu, TPR juga memfasilitasi penguatan daya ingat siswa dalam perkembangan berbicara. Daya ingat merupakan salah satu hambatan tunarungu dalam belajar bahasa. Daya ingat siswa tunarungu kualitasnya relatif singkat.

Ingatan sangat penting dalam berbicara sebab merupakan rujukan sekaligus referensi bahasa yang disimpan dan digunakan sebagai kata dalam berbicara. Sebuah kata dapat dengan mudah diingat dan digunakan (recalling) jika penutur memiliki pengalaman langsung mengenai kata tersebut (Nasution, 2009).

\section{SIMPULAN}

Anak tunarungu memiliki keterbatasan dalam berbicara karena terkendala dalam proses imitasi bahasa. Pendengaran anak tunarungu kurang berfungsi, sehingga aktivitas kebahasaan-nya dialihkan pada visualisasi dan kegiatan motorik. Adanya hambatan akibat gangguan pendengaran turut membuat kemampuan berbicara dan membacanya menjadi terganggu. Bentuk keterbatasan ujaran anak tunarungu terdapat pada ritme dan pemenggalan frasa. Suaranya agak monoton dan tidak ekspresif, serta tidak dapat menghasilkan warna suara yang alami. Selain itu, terdapat kesalahan artikulasi pada bunyi-bunyi 
ujaran tertentu, sehingga dapat dikatakan bahwa kurang dapat dipahaminya ujaran individu anak tunarungu lebih banyak diakibatkan oleh tidak normalnya ritme dan pemenggalan frasa daripada karena kesalahan artikulasi. Untuk meningkatkan kemampuan berbicara anak tunarungu yang memiliki gangguan pendengaran, dapat dilakukan dengan menggunakan teknik Total Physical Response (TPR). TPR merupakan sebuah metode pengajaran bahasa yang lebih menekankan pada proses visualisasi dan perintah langsung. Pengajaran ini lebih mengutamakan kegiatan langsung berhu-bungan dengan kegiatan fisik (physical) dan gerakan (movement). TPR merupakan metode pembelajaran bahasa yang disusun pada koordinasi perintah (command), ucapan (speech), gerak (action), dan berusaha mengajarkan bahasa melalui aktivitas fisik.

\section{DAFTAR PUSTAKA}

Delphie, B. (2006). Pembelajaran Anak Berkebutuhan Khusus (dalam Setting Pendidikan Inklusi). Bandung: PT. Refika Aditama.

Hermin. (2006). Identifikasi Kesulitan Pengucapan Bahasa Ujaran Murid Tunarungu Kelas Dasar III SLB Bagian D YPAC Makassar. Skripsi. Makassar: FIP UNM.

Mansyur, U. (2016). Bahasa Indonesia dalam Belitan Media Sosial: Dari Cabe-Cabean Hingga Tafsir AlMaidah 51. http://doi.org/10.17605/OSF.IO/7VPJ $\underline{\mathrm{H}}$.

Mansyur, U. (2016). Inovasi Pembelajaran Bahasa Indonesia melalui Pendekatan Proses. Retorika: Jurnal Bahasa, Sastra, dan Pengajarannya, 9(2), 158-163.
Mansyur, U. (2017). Peranan Etika Tutur Bahasa Indonesia dalam Pembelajaran di Sekolah. https://doi.org/10.31227/osf.io/wrs9d.

Mansyur, U. (2018). Pembelajaran Inovatif Bahasa Indonesia di Sekolah Dasar. https://doi.org/10.31227/osf.io/fyr8g.

Mardhiati, A. (2010). Peningkatan Kemampuan Berbicara Siswa Tunarungu melalui Teknik Total Physical Response Siswa Kelas IV SDLB-B Pembina Tingkat Propinsi Sul-Sel. Skripsi. Makassar: FBS Uiversitas Negeri Makassar.

Nasution. (2009). Berbagai Pendekatan dalam Proses Belajar dan Mengajar. Jakarta: Bumi Aksara.

Rakhmat, J. (2007). Retorika Modern. Bandung: PT Remaja Rosdakarya.

Soemantri, S. T. (2006). Psikologi Anak Luar Biasa. Bandung: Refika Aditama.

Somad, P. \& Hernawati, T. (1996). Ortopedagogik Anak Tunarungu. Bandung: Depdikbud.

Tarigan, H.G. (2004). Berbicara sebagai Suatu Keterampilan Berbahasa. Bandung: Angkasa.

Umiaty, M. \& Mansyur, U. (2017). Learning Community dalam Pembelajaran Keterampilan Berbicara Bahasa Inggris Siswa Kelas XII SMA LPP UMI Makassar. Retorika: Jurnal Bahasa, Sastra, dan Pengajarannya, 10(1), 13-19. 